\title{
Design and Characterization of Resistance Sensor to Optimize the Manufacturing of Infuse Water Lemon and Sprite Water Lymon Detection System
}

\author{
Fia Ismi Nur Alfiah*, Dinda Salsabila P, Frida Agung Rakhmadi \\ Physics Department, Faculty of Science and Technology, UIN Sunan Kalijaga \\ Email*: fiaismi25.fina@gmail.com
}

\begin{abstract}
This research was purposed to design and characterize a resistance sensor. This research was conducted with three phases: designing, manufacturing and characterization of resistance sensor. Sensor design was done using the 3D paint software. The tools used in sensor manufacturing were PCB, resistors, and copper wire. The tools used in sensor characterization were power supply, ohmmeter and samples of infuse water lemon and sprite water lymon. Sensor characterization was done by varying samples of $50 \mathrm{ml}, 100 \mathrm{ml}, 150 \mathrm{ml}$. Data acquisition for each of samples was repeated 3 times. The result of this research was showed an average and unpredictability with the repeatability resistance sensor on the sample of infuse water lemon $(1,215 \pm 0,723) \mathrm{V}$ with repeatability $99.05 \%$ while for samples of sprite water lymon amounting to $(1,12 \pm 1,345) \mathrm{V}$ with repeatability $99.24 \%$. And was retrieved the value of the transfer function for sample infuse water lemon is $\mathrm{y}=(4,757-0.03542 \mathrm{x})$ and for sample sprite water lymon is $\mathrm{y}=(1.40666-0.0028666 \mathrm{x})$. This tool can be developed as a detection tool using resistance-based sensors.
\end{abstract}

Keywords: Characterization, infuse water lemon, sprite water lymon, resistance sensor

\section{INTRODUCTION}

Infused water is water mixed with pieces of fruit and allowed to stand for several hours until the juice comes out, then it is ready to be consumed, giving it a taste and health benefits. One of infused water known to the public is infused water from lemons. Infused water is different from juice, because it does not use sugar additives or other additives so that, infused water is more natural for consumption. Meanwhile, Sprite water lymon is a branded sprite drink with a lighter flavor. The sensor is an electronic device that can convert physical quantities into electrical signals. The sensor can be applied in various electrical measurements. In this research, a resistance-based sensor was made to optimize the detection system used infused water lemon and sprite water lymon which is made simply. The purpose of made this sensor was to determine the characteristics of resistance sensors in the form of repeatability, transfer function and linear correlation. So that, later it can be developed into a detection system. The quality of a drink depends mostly on the ingredients it makes, this is why this research tried to found the resistance value between infused water lemon and sprite water lymon, because the drinking water content was different. the design made the simplest design, so that, it can be useful for others who are taking care of their health. (example: diet).

\section{MATERIALS AND METHODS}

This research was carried out through three stages, namely designing resistance sensors, making sensors, and characterizing data. The three stages are explained in more detail as follows. The first stage is designed a resistance sensor. The target is achieved by produced a resistance sensor design so that the design is more leverage. The tool needed to make the circuit schematic design used 3D paint software. The second stage was made a resistance sensor. After the design is made, the sensor is made using the necessary materials, namely $22 \mathrm{~K} \Omega$ resistor, connecting cable, and PCB. At this stage the taget achieved is the generation of a resistance sensor to detect a sample.

The last stage is to characterize the sensors that have been made. The target achieved at this stage is to get the characterization value from the sensor which includes the average value, uncertainty, and precision. The tools used in this research are digital ohmmeter and measuring cup. While the ingredients used are lemon infusion water and sprite water lymon water. In characterizing the sensor, the experiment was carried out by varying the volume of $50 \mathrm{ml}, 100 \mathrm{ml}$, and $150 \mathrm{ml}$ in each sample. Measurement using a resistance sensor is carried out three times for each volume repetition. At this stage the results obtained in the form of experimental tables and graphs using infused water lemon and sprite water lymon samples. After that the data analysis was then performed. Data analysis was done by found the average value. To get the average value used the following equation:

$$
\bar{V}=\Sigma \operatorname{Vin}(1)
$$

With is the average resistance value and $n$ is the number of measurements. After obtained an average 
value of resistance, proceed with determining the uncertainty value of the experiment using the equation:

$$
\Delta V=1 n \sqrt{ } n \Sigma V i 2-\Sigma V i 2 n-1 \text { (2) }
$$

To get repeatability values use the equation:

$$
\begin{gathered}
\delta=\Delta F S \times 100 \% \\
\text { Repeatability }=100 \%-\delta(3)
\end{gathered}
$$

The value of a represents zero offset (i.e. slip). The output signal when the zero input signal can be used:

$$
a=\Sigma V i \Sigma X i 2-\Sigma X i \Sigma X i V i n \Sigma X i 2-(\Sigma X i) 2(4)
$$

The value of $b$ represented the slope, which is often called sensitivity and resolution. The equation can be used:

$$
b=n \Sigma X i V i-\Sigma X i \Sigma V i n \Sigma X i 2-(\Sigma X i) 2(5)
$$

Based on the results obtained from this calculation, the resistance sensor transfer function can be determined:

$$
V=a+b x(6)
$$

From the data generated, the sensor can be trusted by calculating the linear correlation coefficient of the equation:

$$
\begin{gathered}
r=n \Sigma X i V i-\Sigma X i \Sigma V i \sqrt{[n \Sigma X i 2-(\Sigma X i) 2][n \Sigma V i 2-(\Sigma V i) 2]} \\
\%=|r \times 100 \%|
\end{gathered}
$$

\section{RESULTS AND DISCUSSION}

\section{Sensor Design}

The results of sensor design using 3D paint software produce images like in Figure 1.

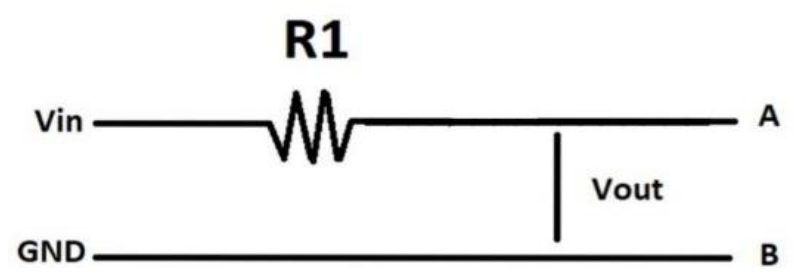

Figure 1. Result of sensor design.

The sensor uses a PCB as a container as shown in Figure 2. Red and white cables will be connected to the ohmmeter as data will be measured. Black and yellow cables are connected to the power supply as a voltage source. On the PCB there are two wires that are left separate and later will be connected by samples. When the two lines are connected there will be a principle of voltage divider where there are two resistances namely the $22 \mathrm{~K} \Omega$ resistor and the resistance that appears from the sample. The connecting cable is dipped to the bottom of the beaker glass which will then be filled with a variable volume variation. The distance between the two connecting cables to be dipped into the beaker glass was set as far as $2 \mathrm{~cm}$. The voltage value recorded is the voltage value at 10th second. Data retrieval is done in three repetitions.

\section{Sensor Making}

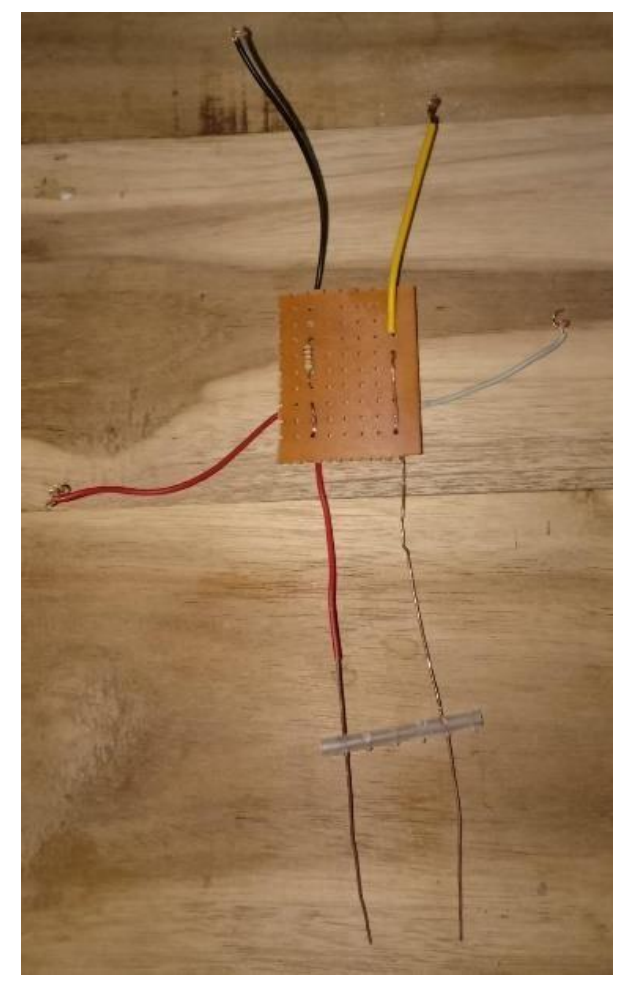

Figure 2. Result of sensor making.

The sensor useds a PCB, $22 \mathrm{~K} \Omega$ resistor and cable. The sensor is made as in the design shown in Figure 2. The results of the manufacture there are two lines on a 2 $\mathrm{cm}$ separate wire. Based on Figure 2, the white and red wires are connected to the ohmmeter. While the black and yellow cable was connected to the battery as a voltage source. The bottom part of the black and yellow cable is the part of the wire that is dipped in a sample of lemon infused water with sprite water lymon. When connected to a voltage source and the PCB dipped into a beverage sample and the circuit is connected, a voltage divider principle will occur. The voltage divider occurs because there are two resistances namely the resistor and the sample.

\section{Sensor Characterization}

Research on resistance sensors is carried out to determine the characteristics of these sensors related to repeatability, transfer function and linear correlation of 
the resistance sensors. The results of the static characteristics of this study, among others, have a repeatability of $99.05 \%$; transfer function $\mathrm{V}=4.757$ $0.03542 \mathrm{x}$ and linear correlation $\mathrm{r}=95.73 \%$ in infused lemon drinking water samples and in sprite water lymon samples having $99.24 \%$ repeatability; transfer function $\mathrm{V}$ $=1.40666-0,00028666 \mathrm{x}$ and linear correlation $\mathrm{r}=97.1 \%$. From the research that has been done resistance sensors have quite good and trusted characteristics.

Table 1. Data Prosessing result

\begin{tabular}{ll}
\hline Sampel & $\overline{\mathbf{V}} \pm \Delta \mathrm{V}$ \\
\hline Infused Water Lemon & $1,215 \pm 0,723$ \\
Sprite Water Lymon & $1,12 \pm 1,345$ \\
\hline
\end{tabular}

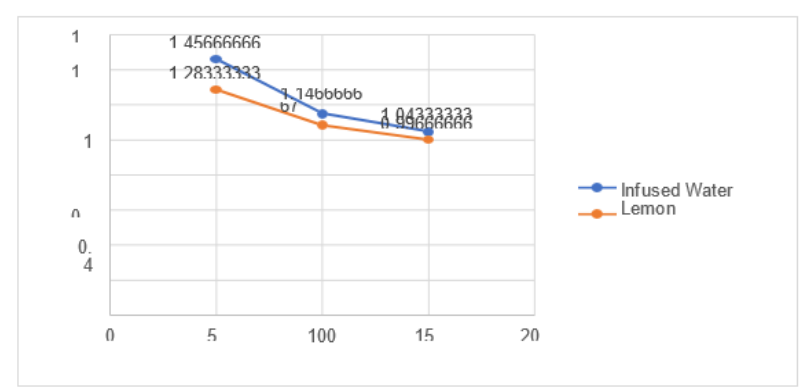

Figure 3. data prosessing result of infused water lemon dan sprite water lymon.

From the results of data processing showed the sample of infused water lemon with sprite water lymon water does not overlap, where the infused water lemon sample was in the range of the average range of the tension value. The data can be clearly distinguished from the voltage value. Therefore, from this data can be used as a basis for making detection systems.

\section{CONCLUSION}

The result of this research was showed an average and unpredictability with the repeatability resistance sensor on the sample of infuse water lemon $(1,215 \pm 0,723) \mathrm{V}$ with repeatability $99.05 \%$ while for samples of sprite water lymon amounting to $(1,12 \pm 1,345) \mathrm{V}$ with repeatability $99.24 \%$. And was retrieved the value of the transfer function for sample infuse water lemon is $\mathrm{y}=$ $(4,757-0.03542 \mathrm{x})$ and for sample sprite water lymon is $\mathrm{y}$ $=(1.40666-0.0028666 \mathrm{x})$. This tool can be developed as a detection tool using resistance-based sensors.

\section{ACKNOWLEDGEMENTS}

Thus the research report was made, thank you to all those who participated in this study starting from $\mathrm{Mr}$. Frida Agung Rakhmadi, S.si., M.Sc. as the supervisor, friends who support and other parties who participated in the research process.

\section{REFERENCES}

Morris, Alan S. Langari, Reza. 1948. Measurement and Instrumentation Theory and Application, USA.

Nizhar, U. 2012. Level Optimum Sari Buah Lemon (Citrus Limon) Sebagai Bahan Penggumpal Pada Pembentukan Curd Keju Cottage. Skripsi. Fakultas Pertanian UNHAS: Makassar

Suhartatik, Nanik, et. al. 2016. Aktivitas Antioksidan Infused Water dengan Variasi Jenis Jeruk (Nipis, Lemon dan Baby) dan Buah Tambahan (Stroberi, Anggur Hitam dan Kiwi) "Jurnal Teknologi dan Industri Pangan". Surakarta 1: 54-55

Suryono. 2018. Teknologi Sensor "Konsep Fisis dan Teknik Akuisisi Data Berbasis Mikrokontroler 32 Bit AT91SAM3X8E (ARDUINO DUE)” Edisi 1. Semarang: Undip Press.

www.thecocopost.id/snack-time-sprite-waterlymon/_access Thuesday, 24 October 2019 
THIS PAGE INTENTIONALLY LEFT BLANK 